\title{
Structural and Optical Properties of Indium Sulfide Thin Films Prepared by Silar Technique
}

\author{
Anita R. Warrier*, Teny Theresa John, K.P. Vijayakumar ${ }^{*}$, C. Sudha Kartha \\ Department of Physics, Cochin University of Science and Technology, Cochin-682 022, India
}

\begin{abstract}
Indium sulfide thin films were prepared using a relatively new, simple and inexpensive technique called Successive Ionic Layer Adsorption and Reaction (SILAR). SILAR deposition conditions for obtaining good quality $\beta$-Indium sulfide $\left(\operatorname{In}_{2} \mathrm{~S}_{3}\right)$ films were optimized. The films were structurally and optically characterized using X-ray diffraction (XRD), photosensitivity measurements and optical absorption studies. Effects of using different precursor solutions, indium chloride $\left(\mathrm{InCl}_{3}\right)$ and indium nitrate $\left(\mathrm{In}\left(\mathrm{NO}_{3}\right)_{3}\right)$ and post deposition annealing were also studied. Films fabricated with $\mathrm{In}\left(\mathrm{NO}_{3}\right)_{3}$ showed good crystallinity without any post deposition annealing while films prepared using $\mathrm{InCl}_{3} \mathrm{were}$ crystalline only when annealed at $400^{\circ} \mathrm{C}$. The band gap of the films varied from 2.32 to $2.92 \mathrm{eV}$ depending on the deposition conditions.
\end{abstract}

Keywords: Indium sulfide, SILAR, optical absorption, photosensitivity, annealing, X-ray diffraction.

\section{INTRODUCTION}

$\mathrm{In}_{2} \mathrm{~S}_{3}$ is a wide band gap semiconductor with high photoconductivity and intense luminescence existing in three welldefined crystallographic modifications $[1,2]$. The room temperature phase, called $\beta-\mathrm{In}_{2} \mathrm{~S}_{3}$, is stable up to $420^{\circ} \mathrm{C}$ and crystallizes in defect spinel lattice with high degree of vacancy ordering at tetrahedral cation sites. Above $420^{\circ} \mathrm{C}$, disordering of tetrahedral vacancies occurs, which results in the formation of cubic defect lattice $\left[\alpha-\mathrm{In}_{2} \mathrm{~S}_{3}\right]$ with cation sites and vacancies arranged random. The $\beta$ to $\alpha$ transition at $420^{\circ} \mathrm{C}$ is often suppressed in indium rich material and $\alpha$-modification persists down to room temperature [3]. A third modification with trigonal symmetry has been reported above $754^{\circ} \mathrm{C}$ [4]. This modification can be stabilized to room temperature by the addition of $5 \%$ to $10 \%$ As or Sb [5]. Several of its structural and optical characteristics have been reported [6]. Nanocrystalline powder of $\beta$ - $\mathrm{In}_{2} \mathrm{~S}_{3}$ was prepared by hydrothermal treatment of a sol from indium trichloride and sodium sulfide at $140^{\circ} \mathrm{C}$ [7]. Sung Hyu Choe et al could grow $\beta-\operatorname{In}_{2} \mathrm{~S}_{3}$ and $\beta-\operatorname{In}_{2} \mathrm{~S}_{3} \mathrm{Co}^{2+}$ single crystals by chemical transport reaction method [8]. The effect of various substrates on growth and structure of $\beta-\mathrm{In}_{2} \mathrm{~S}_{3}$ and $\beta-\mathrm{In}_{2-\mathrm{x}} \mathrm{Al}_{\mathrm{x}} \mathrm{S}_{3}$ thin films, prepared using spray pyrolysis technique, have been studied [9]. Acoustic properties of $\beta$ - $\operatorname{In}_{2} \mathrm{~S}_{3}$ were studied and this provided valuable information on structure, morphology and adherence of the film with substrate [10]. N Barreau et al reported the effect of oxygen present in $\beta-\operatorname{In}_{2} \mathrm{~S}_{3}$ films [11]. Infrared, Raman and optical study of $\alpha$ and $\beta-\operatorname{In}_{2} \mathrm{~S}_{3}$ compounds have been reported [12]. Studies on solar cells using nanocrystalline $\mathrm{In}_{2} \mathrm{~S}_{3} / \mathrm{In}_{2} \mathrm{O}_{3}$ thin film electrodes were already reported [13]. $\mathrm{In}_{2} \mathrm{~S}_{3}$ also finds application in preparation of green and red phosphors and manufacture of picture tube for color televisions. They are used in fabrication of dry cell and heterojunctions for use in photoelectric generators.

*Address correspondence to these authors at the Department of Physics, Cochin University of Science and Technology, Cochin- 682 022, India; Tel: + 91 484-257-7103; Fax: +91-484-257-7595;

E-mails:kpv@cusat.ac.in; anuwarrier@yahoo.co.uk
Awareness on the necessity for fabrication of $\mathrm{Cd}$ free buffer layers for solar cell has triggered our interest in getting thin films of $\beta-\operatorname{In}_{2} S_{3}$, which is a promising photoconducting material useful for photovoltaic applications with direct band gap. The films can be synthesized using several techniques such as chemical spray pyrolysis (CSP) [14], atomic layer epitaxy (ALE) [15], chemical bath deposition (CBD) [16], chemical vapor deposition (CVD) [11], RF sputtering [17], thermal evaporation [2], organometallic chemical evaporation [18] and Successive Ionic Layer Adsorption and Reaction (SILAR) [19, 20]. In the present work, we prepared $\beta-\operatorname{In}_{2} S_{3}$ thin films using SILAR deposition technique, which is a convenient and adaptable method for thin film deposition. This technique was first reported in 1985 by Ristov et al [21]. It is an aqueous solution technique, based on sequential reaction at the substrate- solution interface. This technique has been employed for deposition of $\operatorname{In}_{2} \mathrm{~S}_{3}$ [22], CdS [16], ZnS [23], Cd ZnS [24], PbS [25], $\mathrm{Sb}_{2} \mathrm{~S}_{3}$ [26], $\mathrm{ZnO}$ [27] and $\mathrm{SnS}$ [28] and is based on successive reactions of solvated ionic components on the solution-solid interface. Reaction between the anions and cations lead to the formation of the required compound. Solubility constant of the compound formed should be low enough while the byproducts have to be soluble in the given conditions. SILAR also resembles CBD in many ways both being aqueous solution based technique. Both techniques require no complicated apparatus. Film deposition is due to the chemical force between liquid phase ions and surface ions. Main advantages of the technique are that film fabrication can be carried out at atmospheric pressure and room temperature. Hence it is possible to use temperature sensitive substance like polymer substrates. It is also a safe method posing minimum environmental hazards since it avoids reactants in vapor phase. This technique also offers good reproducibility once the deposition parameters are preset. We can also control thickness of the films by fixing the dipping time and number of SILAR cycles. $\mathrm{In}_{2} \mathrm{~S}_{3}$ films prepared using SILAR technique may be used as buffer layer in solar cell fabrication. The low production cost and ease of deposition are the other advan- 
tages of this technique. This work reports deposition of crystalline $\beta-\operatorname{In}_{2} \mathrm{~S}_{3}$ films with direct band gap on glass slides either by varying the precursor solution or by post deposition annealing. A comparison of structural and optical properties of the films prepared using chloride based and nitrate based precursors is discussed in this paper.

\section{EXPERIMENTAL DETAILS}

Basic requirement for depositing thin films using SILAR technique is to have an arrangement for substrate to make contact with the precursor solution. It requires a mechanism to introduce substrates into beakers containing the chemical solutions and distilled water (for rinsing) at room temperature. Here, a microprocessor unit controls the dip mechanism. It introduces substrates into various beakers for a specific interval of time. Immersion- reaction- rinsing cycles can be repeated any number of times. The equipment consists of a central unit, having a microprocessor arrangement and stepper motor to control the movement of substrate holder. The substrate holder can be moved in vertical (up and down) as well as horizontal (rotation around its own axis) mode. Once the substrate holder moves down, the substrates will be dipped into the solution or rinsing water. After the required time interval, it moves upwards, rotates by 90 degree and then makes a downward motion to repeat the dipping process. In the present work, we used four glass beakers of 50 $\mathrm{ml}$, either containing the required solution or distilled water. The beakers were placed on four sides of a tray, around the sample holder fixed on a motor shaft. The sample holder has two arms to which two or more substrates can be attached. This shaft can turn and slide through a bearing. Two stepper motors, whose working is controlled by a microprocessor, drive the motions. Fig. (1) shows the sketch of SILAR set up used in this work. Dipping timings in the solution and distilled water can be varied from one to hundred seconds and number of SILAR cycles from one to five hundred. After five to ten cycles we replaced the rinsing water. This replacement of new water depends on the dipping timing in cationic and anionic precursors. The beakers containing solution and rinsing water are intercalated, each rinsing vessel being placed between a beaker containing solution of the salt of cation and the other containing solution of the salt of anion.

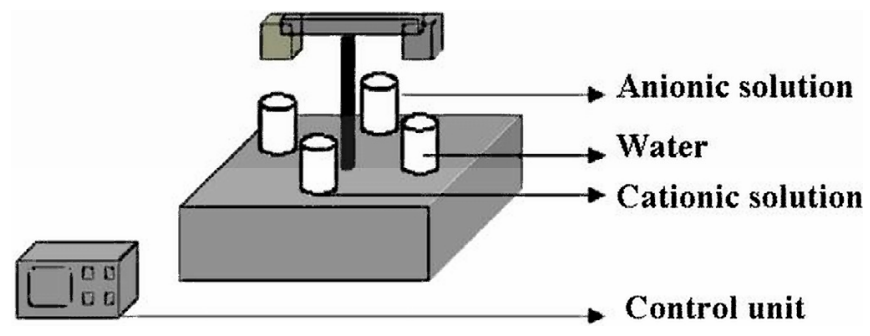

Fig. (1). Sketch of the SILAR setup with control unit.

Micro glass slides $(6 \mathrm{~cm} \times 1.25 \mathrm{~cm})$ were cleaned thoroughly using soap solution to remove visible impurities and kept in chromic acid for 15 minutes. Later the slides were rinsed with distilled water. Two sets of Samples were prepared, one set using $\mathrm{InCl}_{3}$ and the other using In $\left(\mathrm{NO}_{3}\right)_{3}$ as the cationic solution. The anionic precursor was $\mathrm{Na}_{2} \mathrm{~S}$ solution for both the sets. Molar ratio between Indium and Sulfur was kept 1:1 for all the samples. Dipping time in precursor solution was varied from $2 \mathrm{~s}$ to $15 \mathrm{~s}$ in both cases. The sam- ples were named in accordance with the dipping time as ' $A \mathrm{~s} B \mathrm{w}$ ' where ' $A$ ' corresponds to dipping time in solution and ' $B$ ' the dipping time in water. Further the samples prepared using $\mathrm{InCl}_{3}$ were named 'ICAsBw' and those prepared using $\mathrm{In}\left(\mathrm{NO}_{3}\right)_{3}$ were named 'INAsBw'.

Cleaned glass substrates were immersed for ' $n$ ' seconds in cationic precursor. This resulted in adsorption of Indium ions on to substrate surface. It was then immersed in distilled water for ' $\mathrm{n}_{0}$ ' seconds, in order to remove the de-adsorbed ions. These substrates were again immersed in for ' $n$ ' seconds in anionic precursor leading to adsorption and reaction of sulfide ions. Unreacted sulfide ions were removed by rinsing them in distilled water for ' $n_{0}$ ' seconds. Thus a SILAR cycle is completed after these four operations. Repetition of SILAR cycle resulted in deposition of a thin layer of $\mathrm{In}_{2} \mathrm{~S}_{3}$ on the substrate. These samples were annealed in vacuum at $100^{\circ} \mathrm{C}, 200^{\circ} \mathrm{C}$, $300^{\circ} \mathrm{C}$ and $400^{\circ} \mathrm{C}$ for one hour [pressure $\sim 10^{-5} \mathrm{Torr}$ ], in a chamber, made of glass tube over which Nichrome wire was wound uniformly along the entire length. This tube was heated by passing current through the Nichrome wire. Control of the temperature was achieved by adjusting the current. Four samples were placed in the vacuum chamber at a time. Temperature of sample was measured using chromel-alumel thermocouple, kept in contact with the samples. In all the cases, heating and cooling rate was $3^{0} \mathrm{C} /$ minute.

Structural analysis was performed using x-ray diffraction (XRD) with a Rigaku (D.Max.C) x-ray diffractometer $\left(\mathrm{CuK}_{\alpha}\right.$ $\left(\lambda=1.5405 \mathrm{~A}^{\circ}\right)$ radiation and $\mathrm{Ni}$ filter operated at $30 \mathrm{kV}$ and $20 \mathrm{~mA}$ ). Grain size of the films was calculated from the XRD pattern using Debye Scherrer's formula, $L=k \lambda / \beta \cos \theta$, where $L$ is the grain size, $\beta$ is the full width half maximum of the peak (usually measured in radians). Optical absorption studies were carried out employing UV-VIS-NIR spectrophotometer (Hitachi model U-3410). Photosensitivity measurements were performed using Keithley 236 Source Measure Unit. The samples were illuminated with the help of a tungsten halogen lamp (white light) with intensity $60 \mathrm{~mW}$ $\mathrm{cm}^{-2}$. IR filter and water column were placed between the source and sample to avoid heating of the sample. The electric field applied to the film was $1000 \mathrm{~V} \mathrm{~m}^{-1}$. Silver electrodes were painted on the surface of the film on a fixed area with uniform thickness, keeping a distance of $5 \mathrm{~mm}$ between the electrodes, for photosensitivity measurements. Photosensitivity is measured from the formula, $G=\frac{I_{L}-I_{D}}{I_{D}}$, where $\mathrm{G}$ is the photosensitivity; $I_{L}$ is the illuminated current and $I_{D}$ the dark current and is measured in arbitrary units (a.u).

\section{RESULTS AND DISCUSSION}

Two sets of samples were prepared, one using $\mathrm{InCl}_{3}$ and sodium sulfide $\left(\mathrm{Na}_{2} \mathrm{~S}\right)$ and other using $\operatorname{In}\left(\mathrm{NO}_{3}\right)_{3}$ and $\mathrm{Na}_{2} \mathrm{~S}$ as precursor solutions. The dipping timings were varied from 2 to 15 seconds at room temperature. The number of SILAR cycles was kept 300 for all samples. When number of cycles was increased more than 300 , film pealed off the substrate. Samples prepared using $\mathrm{InCl}_{3}$ and $\mathrm{Na}_{2} \mathrm{~S}$ were yellow in color with good adhesion to the substrate; etching could be done with dilute hydrochloric acid. XRD pattern showed that all these samples were amorphous. It has been reported earlier that indium sulfide films prepared using $\mathrm{InCl}_{3}$ at room tem- 
perature through CBD and SILAR methods were also amorphous $[16,19,20]$. It was also reported that samples prepared using this method at deposition times $2 \mathrm{~s}$ and $6 \mathrm{~s}$ in precursor solution could be made crystalline upon annealing at $400^{\circ} \mathrm{C}[20]$. Annealing temperature (Ta) is very important in the crystalline properties of the films.

In the present work also samples prepared at $5 \mathrm{~s}, 8 \mathrm{~s}, 10 \mathrm{~s}$, $12 \mathrm{~s}, 15 \mathrm{~s}$ remained amorphous even after annealing at $100^{\circ} \mathrm{C}$, $200^{\circ} \mathrm{C}$ and $300^{\circ} \mathrm{C}$. But the sample annealed at $400^{\circ} \mathrm{C}$ showed crystalline nature having characteristic peaks of $\beta$ - $\operatorname{In}_{2} \mathrm{~S}_{3}$ with tetragonal structure (Fig. 2). The d-values coincided with JCPDS file 25-390 as in Table 1. It is also clear from the XRD pattern that samples IC10s2w exhibited better crystalline nature compared to other samples (Fig. 3). The sample IC2s10w having longer dipping time in water had poor crystallinity (Fig. 4). Grain size of these samples was calculated using Debye Scherer's formula and this very well corroborated our observation that IC10s $2 \mathrm{w}$ had better crystallinity. IC10s2w had grain size of $8.7 \mathrm{~nm}$ while IC2s10w films had grains of size $4.3 \mathrm{~nm}$. However the grain size was found to increase with increase in dipping time in precursor solution (Fig. 3)

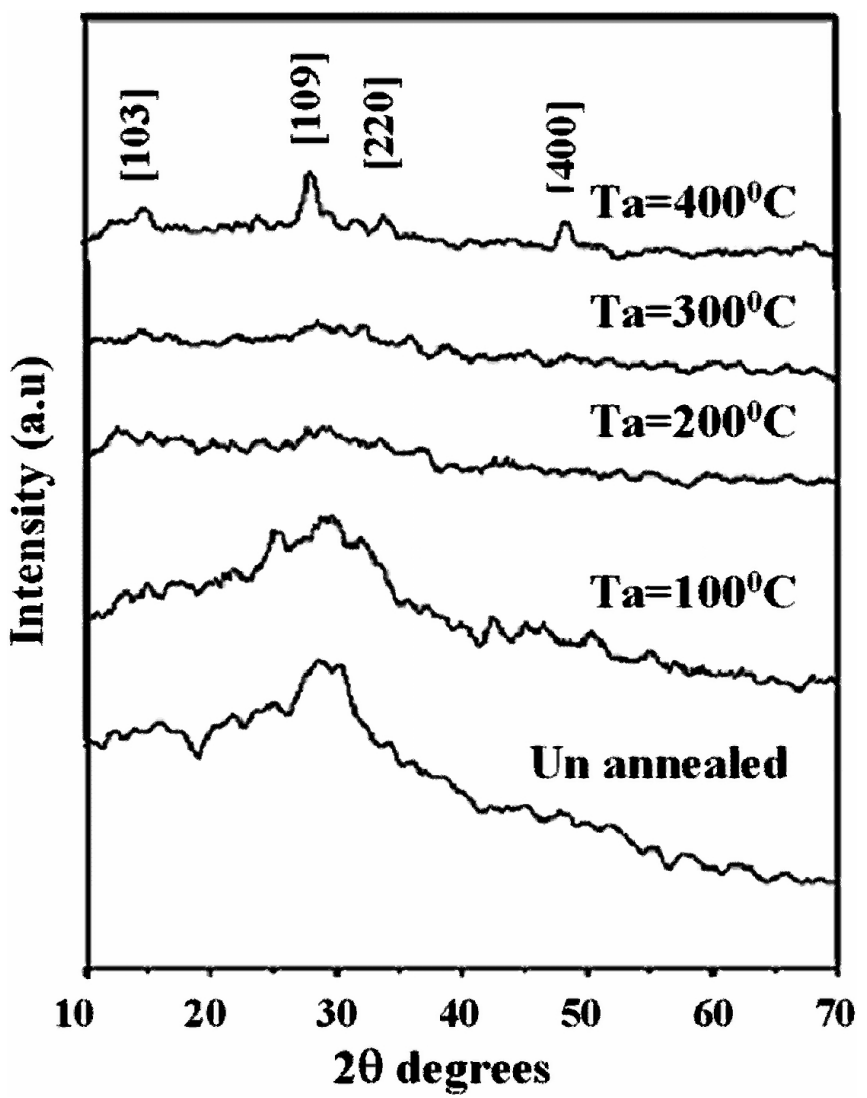

Fig. (2). XRD Pattern of IC10s $2 \mathrm{w}$; pristine and annealed at $100^{\circ} \mathrm{C}$, $200^{\circ} \mathrm{C}, 300^{\circ} \mathrm{C}, 400^{\circ} \mathrm{C}$.

The energy band gap calculated from the plot of $(\alpha h v)^{2}$ $v s$ hv, [where ' $h$ ' is the Planck's constant and ' $v$ ' is the frequency], shows that all samples had direct band gap which slightly increase (from $2.26 \mathrm{eV}$ to $2.54 \mathrm{eV}$ ) with decrease in dipping time in solution (from $15 \mathrm{~s}$ to $5 \mathrm{~s}$ ). The sample IC10s $2 \mathrm{w}$ had band gap of $2.32 \mathrm{eV}$ while for IC2s10w band

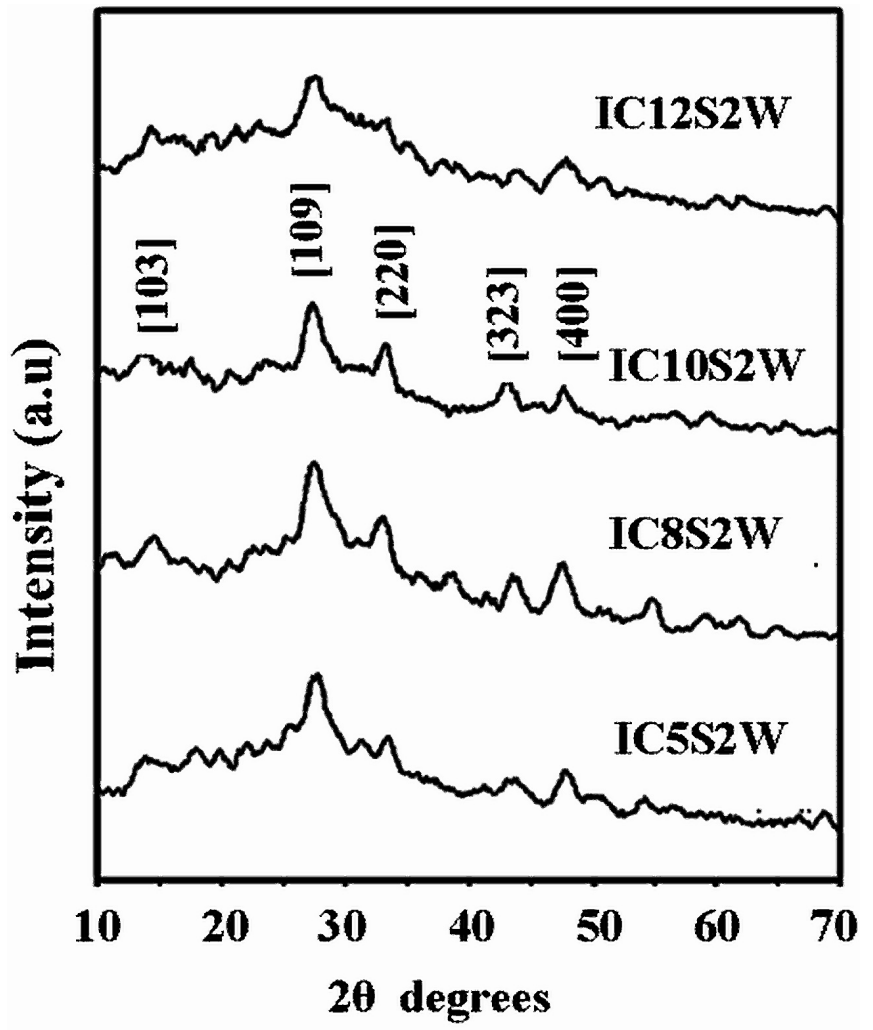

Fig. (3). XRD Pattern of IC5s $2 w$, IC $8 s 2 w, I C 10 s 2 w$, and IC12s $2 w$ annealed at $400^{\circ} \mathrm{C}$.

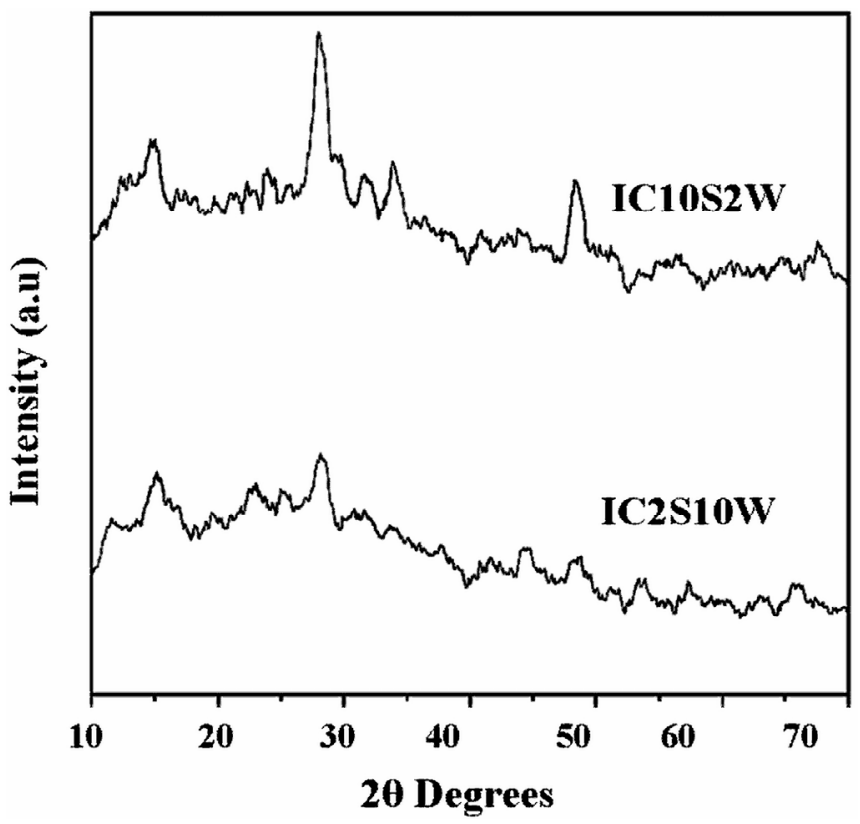

Fig. (4). XRD pattern of IC10s $2 \mathrm{w}$ and IC2s $10 \mathrm{w}$ annealed at $400^{\circ} \mathrm{C}$. gap increases to $2.92 \mathrm{eV}$ (Fig. 5). Optical band gap of $\beta$ $\mathrm{In}_{2} \mathrm{~S}_{3}$ varies from 2.32 to $2.92 \mathrm{eV}$ when the film was dipped in water for longer time (10s), which might be due to presence of oxygen. Barreau et al have reported similar results in the case of samples using CBD when the substrate is dipped for longer time in water [11]. XPS analysis on $\mathrm{In}_{2} \mathrm{~S}_{3}$ films, prepared using SILAR, also suggests that films prepared with longer dipping time in water contains more oxygen [20]. During the film formation with longer dipping time in 
Table 1. XRD Data of $\beta-\operatorname{In}_{2} S_{3}$ with Tetragonal Structure

\begin{tabular}{|c|c|c|c|c|c|}
\hline $\mathbf{2 \theta}$ & $\begin{array}{c}\mathbf{d}\left(\mathbf{A}^{\mathbf{0}}\right) \\
\text { Standard }\end{array}$ & $\begin{array}{c}\mathbf{d}\left(\mathbf{A}^{\mathbf{0}}\right) \\
\text { Observed }\end{array}$ & $\mathbf{h} \mathbf{k} \mathbf{~}$ & $\begin{array}{c}\mathbf{I} / \mathbf{I} 0 \\
\text { Standard }\end{array}$ & $\begin{array}{c}\mathbf{I} / \mathbf{I o} \\
\text { Observed }\end{array}$ \\
\hline \hline 14.30 & 6.21 & 6.18 & 103 & 30 & 22.53 \\
\hline 27.57 & 3.24 & 3.24 & 109 & 100 & 100 \\
\hline 33.30 & 2.69 & 2.68 & 220 & 50 & 64.86 \\
\hline 44.74 & 2.07 & 2.06 & 323 & 45 & 23.41 \\
\hline 47.82 & 1.90 & 1.90 & 400 & 65 & 37.55 \\
\hline
\end{tabular}

water, the grain growth is also affected leading to small grains and poor crystallinity. This may also lead to the wider band gap.

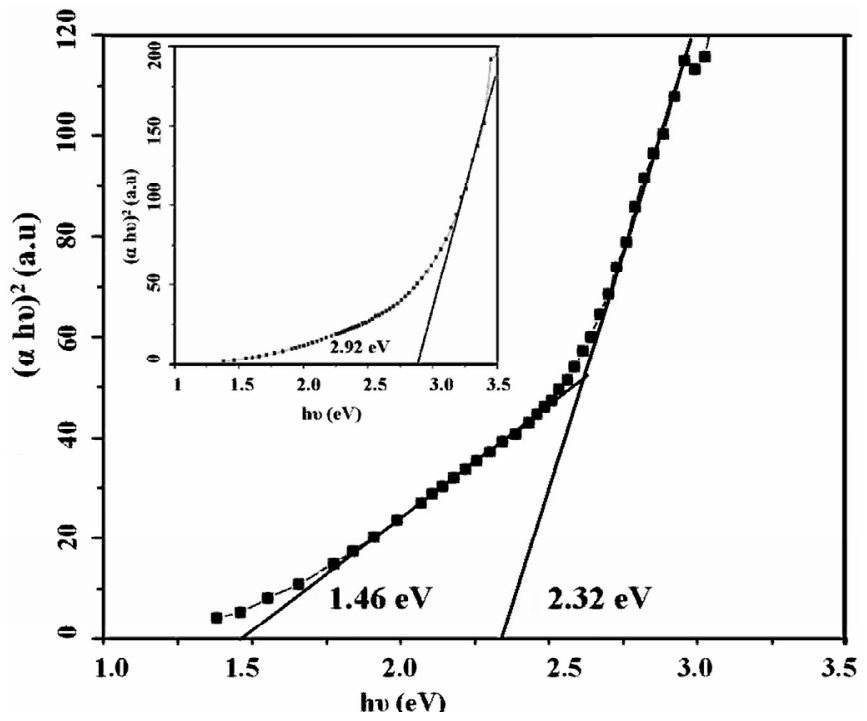

Fig. (5). Band gap energy of pristine IC10s2w. (Inset: Energy band gap of pristine IC2s10w).

Upon annealing at $400^{\circ} \mathrm{C}$ the band gap of samples (IC5s $2 \mathrm{w}, \mathrm{IC} 8 \mathrm{~s} 2 \mathrm{w}, \mathrm{IC} 10 \mathrm{~s} 2 \mathrm{w}, \mathrm{IC} 12 \mathrm{~s} 2 \mathrm{w}$ and IC $15 \mathrm{~s} 2 \mathrm{w}$ ) reduced to $1.69 \mathrm{eV}$ (Fig. 6). In the case of IC2s10w band gap reduces to $2.04 \mathrm{eV}$ when annealed at $400^{\circ} \mathrm{C}$. Vapor pressure of sulfur is very high and hence some sulfur may be escaping during annealing at $400^{\circ} \mathrm{C}$. This might be one of the causes for reduction in bandgap on annealing. From Fig. (5), we find that apart from the band gap absorption at $2.32 \mathrm{eV}$ there is a defect level absorption at $1.46 \mathrm{eV}$. But on annealing, this distinction between the two levels disappeared and the band gap reduces to $1.69 \mathrm{eV}$. This decrease in band gap upon annealing at $400^{\circ} \mathrm{C}$ is attributed to the increase in the defect concentration below conduction band, which can be observed from the absorption spectra of both pristine and annealed samples [IC10s2w]. From Fig. (5) and Fig. (6), we observe that the absorbance for the annealed samples is much higher than the pristine due to the increase in defect concentration. This increase in absorbance for samples with better crystallinity might have been due to increase in oscillator strength.

All samples had low photoresponse with the photosensitivity varying from 0.3 to 2.0 and this increased upon annealing. Maximum photosensitivity of 2 was obtained for

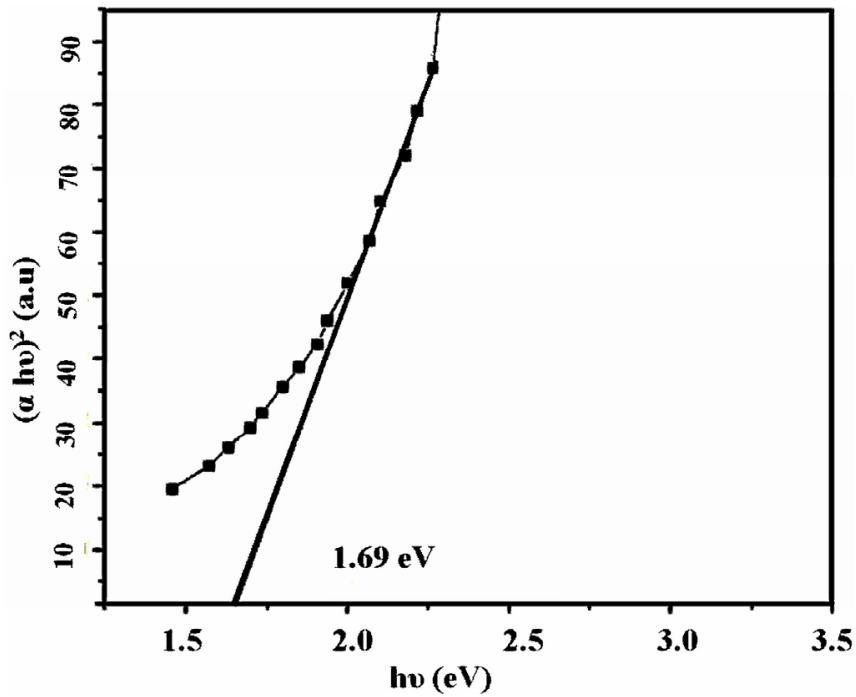

Fig. (6). Band gap energy of IC $10 \mathrm{~s} 2 \mathrm{w}$ annealed at $400^{\circ} \mathrm{C}$.

IC10s $2 \mathrm{w}$, which increased to 9.11 when annealed at $400^{\circ} \mathrm{C}$. Probably the creation of more defect states below the conduction band upon annealing must be contributing to the increase in photoresponse. Number of SILAR cycles used for film fabrication was also found to affect film properties. At least 100 SILAR cycles were required for fabrication of uniform films. Below 100 cycles, the films were highly porous. The band gap decreased from $2.54 \mathrm{eV}$ to $2.32 \mathrm{eV}$ with increase in SILAR cycles from 100 to 300 . The grain size increased with increase in SILAR cycles. But films deposited using 400 cycles were again porous. Hence we may conclude that for films fabricated using $\mathrm{InCl}_{3}$ and with $10 \mathrm{~s}$ dipping time in solution and $2 \mathrm{~s}$ in water, 300 SILAR cycles could give films of better properties in terms of band gap, crystallinity and photosensitivity.

The films prepared using In $\left(\mathrm{NO}_{3}\right)_{3}$ and $\mathrm{Na}_{2} \mathrm{~S}$ were orange in color and were less adhesive to substrate. These films pealed off the substrate on annealing at temperature higher than $100^{\circ} \mathrm{C}$. So studies on samples annealed at temperature higher than $100^{\circ} \mathrm{C}$ could not be done. The samples turned red on annealing, with the redness increasing as the annealing temperature increased. The pristine samples showed crystallinity with characteristic peaks corresponding to $\beta$ - $\operatorname{In}_{2} S_{3}$ with cubic structure and $d$ - values coincided with JCPDS file 35 - 0456 (Table 2) [29]. Crystallinity improved up to $8 \mathrm{~s}$ in solution and $2 \mathrm{~s}$ in water (IN8s $2 \mathrm{w}$ ) and slowly reduces with increase in dipping time (Fig. 7). This is also evident from the grain size calculations since the grain size, which decreased with increase in dipping time in solution; grains were large $(12.8 \mathrm{~nm})$ for IN8s2w while it was $8.39 \mathrm{~nm}$ for IN10s $2 \mathrm{w}$ and $5.02 \mathrm{~nm}$ for IN12s2w. But upon annealing at $100^{\circ} \mathrm{C}$ they showed poor crystallinity and grain size reduced to $8.2 \mathrm{~nm}$ for the sample IN10s2w. Being less adhesive to substrate, the grain size might have also diminished upon annealing as the films showed an increasing tendency to peel off the substrate with higher temperatures.

The band gap decreased from $2.05 \mathrm{eV}$ to $1.93 \mathrm{eV}$ on increasing the dipping time from 5 s to 15 s. Sample IN10s 2 w had band gap of $1.97 \mathrm{eV}$ (Fig. 8). Annealing at $100^{\circ} \mathrm{C}$, however, did not affect the band gap. IN10s $2 \mathrm{w}$ had maximum photoresponse of 1.60 and annealing had no effect on 
Table 2. XRD Data of $\beta$ - $\operatorname{In}_{2} S_{3}$ with Cubic Structure

\begin{tabular}{|c|c|c|c|c|c|}
\hline $2 \theta$ & $\begin{array}{c}\mathbf{d}\left(\mathbf{A}^{\mathbf{0}}\right) \\
\text { Standard }\end{array}$ & $\begin{array}{c}\mathbf{d}\left(\mathbf{A}^{\mathbf{0}}\right) \\
\text { Observed }\end{array}$ & $\mathbf{h} \mathbf{k} \mathbf{~}$ & $\begin{array}{c}\mathbf{I} / \mathbf{I} 0 \\
\text { Standard }\end{array}$ & $\begin{array}{c}\text { I/Io } \\
\text { Observed }\end{array}$ \\
\hline \hline 28.64 & 3.09 & 3.11 & 222 & 25 & 93.88 \\
\hline 33.45 & 2.68 & 2.67 & 400 & 50 & 100 \\
\hline 48.07 & 1.89 & 1.89 & 440 & 100 & 89.83 \\
\hline
\end{tabular}

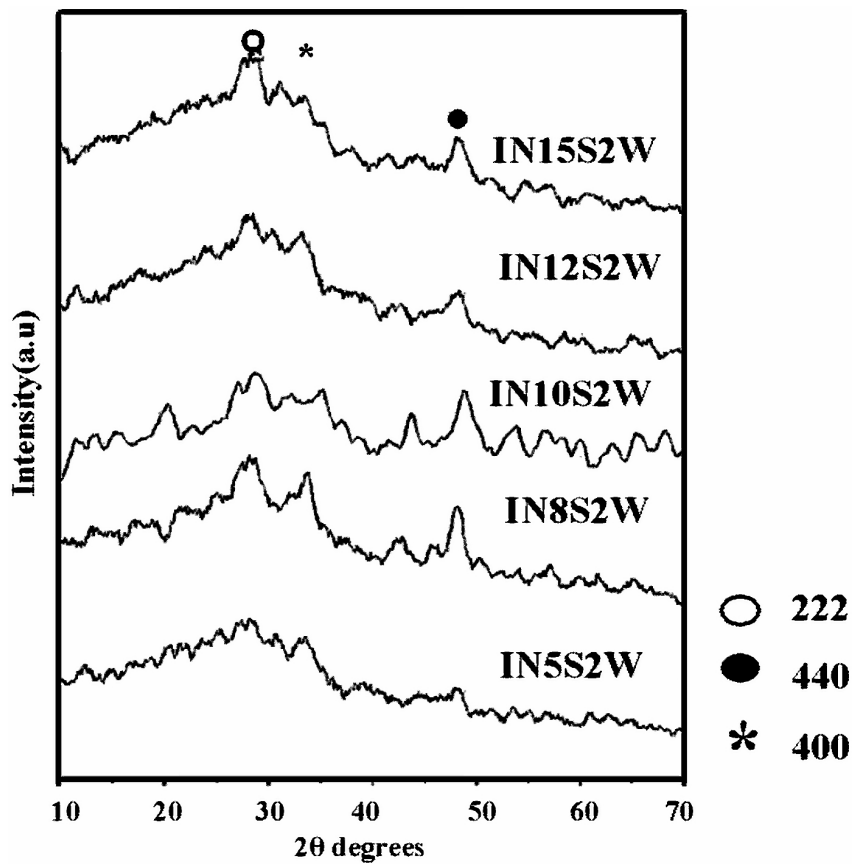

Fig. (7). XRD Pattern of pristine samples prepared using $\operatorname{In}\left(\mathrm{NO}_{3}\right)_{3}$. photosensitivity in this case. Thus the photosensitivity of samples prepared using In $\left(\mathrm{NO}_{3}\right)_{3}$ was lower than those, prepared using $\mathrm{InCl}_{3}$. The difference in photosensitivity of chloride and nitrate based $\mathrm{In}_{2} \mathrm{~S}_{3}$ could also have been due to the difference in band gap. In the case of chloride based sample, before annealing, the band gap was comparable to that of nitrate based sample. In this case the photosensitivity was also comparable. But on annealing the band gap of chloride based samples decreased to $1.69 \mathrm{eV}$ and thus resulted in higher absorption and higher photosensitivity. The increase in grain size for samples prepared with In $\left(\mathrm{NO}_{3}\right)_{3}$ could be the reason why these samples are crystalline in the "asprepared" condition. Hence SILAR appears to be a useful and easy way of deposition of buffer layers, as the required band gap and thickness can be controlled by merely varying the dipping times. Curbing the need for post deposition treatments for obtaining crystalline films by solely changing the precursor solution leaves us with opportunity to deposit of crystalline $\beta-\mathrm{In}_{2} \mathrm{~S}_{3}$ buffer layer directly over the absorber layer of solar cells.

\section{CONCLUSION}

Uniform, crystalline, cubic $\beta-\operatorname{In}_{2} \mathrm{~S}_{3}$ with peak orientation along 440 plane could be fabricated using $\operatorname{In}\left(\mathrm{NO}_{3}\right)_{3}$ as precursor solution. The post deposition treatment (vacuum annealing at $400^{\circ} \mathrm{C}$ ) which was required for obtaining crystalline $\beta-\mathrm{In}_{2} \mathrm{~S}_{3}$ in the case of films using $\mathrm{InCl}_{3}$ as precursor can be curbed by using In $\left(\mathrm{NO}_{3}\right)_{3}$. But films with good photo response were obtained only by annealing the chloride based samples at $400^{\circ} \mathrm{C}$ fabricated using $\mathrm{InCl}_{3}$. The optimum dipping time for obtaining crystalline films with good photosensitivity was $10 \mathrm{~s}$ for chloride based samples and $8 \mathrm{~s}$ for nitrate based samples. Thus SILAR is an easy method for fabricating films which can be used as buffer layers in solar cells.

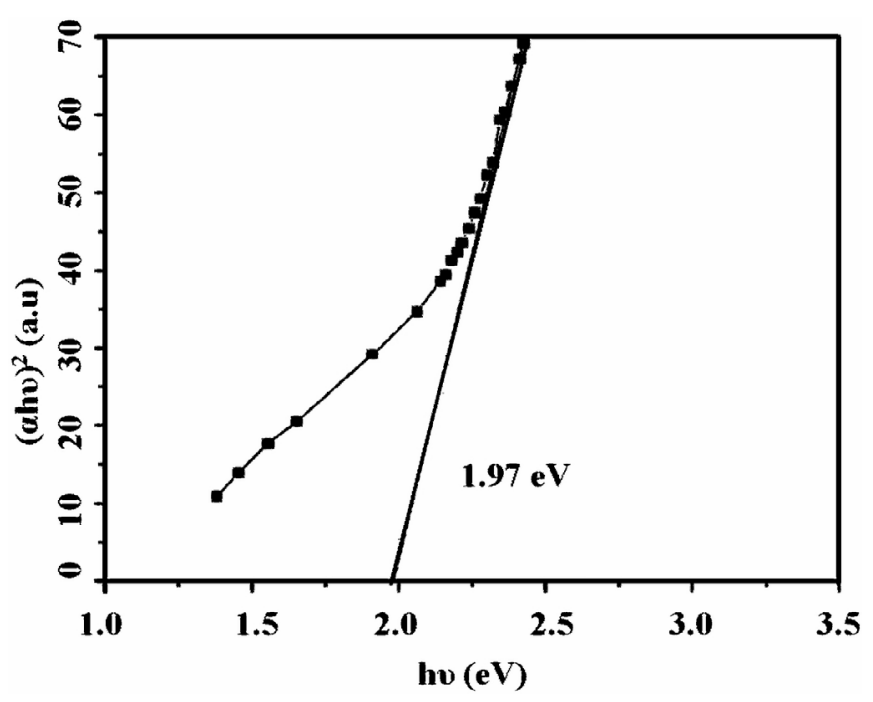

Fig. (8). Band gap of pristine IN10s2w.

\section{ACKNOWLEDGEMENT}

The authors would like to thank DST for funding through project and UGC for the financial support offered through DSA/COSIST schemes. One of the authors [ARW] is grateful to UGC for the fellowship. All authors are thankful to DST for some of the equipments used in this work were purchased with their financial support.

\section{REFERENCES}

[1] George J, Joseph KS, Pradeep B, Palson TI. Reactively evaporated films of indium sulphide. Phys Status Solidi A 1988; 106: 123.

[2] El Shazly AA, Abd Elhady D, Metwally HS, Seyam MAM. Electrical properties of $\beta-\mathrm{In}_{2} \mathrm{~S}_{3}$ thin films. J Phys Condens Matter 1998; 10: 5943-54.

[3] Rooymans CJM. A new type of cation-vacancy ordering in the spinel lattice of $\operatorname{In}_{2} \mathrm{~S}_{3}$. J Inorg Nucl Chem 1959; 11: 78-9.

[4] Diehl R, Nitsche R. Vapour flux growth of $\gamma-\operatorname{In}_{2} \mathrm{~S}_{3}$, a new modification of indium sequisulphide. J Cryst Growth 1973; 20: 38.

[5] Landuyt JV, Hatwell H, Amelinckx S. The domain structure of $\beta$ In2S3"single crystals" due to the ordering of indium vacancies. Mater Res Bull 1968; 3: 519-28.

[6] Kim WT, Kim CD. Optical energy gaps $\beta-\mathrm{In}_{2} \mathrm{~S}_{3}$ thin films grown by spray pyrolysis. J Appl Phys 1986; 60: 2631-3.

[7] Yu S, Shu L, Qain Y, Xie Y, Yang J, Yang L. Hydrothermal preparation and characterization of nanocrystalline powder of $\beta$ - Indium sulfide. Mater Res Bull 1998; 33: 717-21.

[8] Choe SH, Bang TH, Kim NO, et al. Optical properties of $\beta-\mathrm{In}_{2} \mathrm{~S}_{3}$ and $\beta-\mathrm{In}_{2} \mathrm{~S}_{3}: \mathrm{Co}^{2+}$ single crystals. Semicond Sci Tech 2001; 16: 98102 .

[9] Kamoun N, Belgacem S, Amlouk N, Bennaceur R. Structure, surface composition and electronic properties of $\beta-\mathrm{In}_{2} \mathrm{~S}_{3}$ and $\beta$ $\mathrm{In}_{2} \mathrm{~S}_{3} \mathrm{Al}_{\mathrm{x}} \mathrm{S}_{3}$. J Appl Phys 2001; 89: 2766-71.

[10] Amoulk M, Ben Said MA, Kamoun N, Belgacem S, Brunet N, Barjon D. Acoustic properties of $\beta-\mathrm{In}_{2} \mathrm{~S}_{3}$ thin films prepared by spray Japan. J Appl Phys 1999; 38: 26-30

[11] Barreau N, Bernede JC, El Maliki H, Marsillac S, Castel X, Pinel J. Recent studies on $\mathrm{In}_{2} \mathrm{~S}_{3}$ containing oxygen thin films. Solid State Commun 2002; 122: 445-50.

[12] Kambas K, Spyridelis J, and Balkanski M. Far infrared and raman optical study of $\alpha$ - and $\beta$ - $\operatorname{In}_{2} S_{3}$. Phys Stat Sol 1988; 23: 291-6. 
[13] Braunger D, Hariskos D, Waltre H, Schock HW. An 11.4\% efficient polycrystalline thin film solar cell based on $\mathrm{CuInS}_{2}$ with a Cdfree buffer layer. Sol Energy Mater Sol cells 1996; 40: 97.

[14] John TT, Bini S, Kashiwaba Y, et al. Characterization of spray pyrolysed indium sulfide thin films. Semicond Sci Technol 2003: 18: 491-500.

[15] Asikainen T, Ritala M, Leskelä M. Growth of $\operatorname{In}_{2} \mathrm{~S}_{3}$ thin films by atomic layer epitaxy. Appl Surf Sci 1994; 82/83: 122-5.

[16] Lokhande CD, Ennaoui A, Patil PS, et al. Chemical bath deposition of indium sulphide thin films: preparation and characterization. Thin Solid Films 1999; 340: 18-23.

[17] Ihara H, Abe H, Endo S, Irie T. Valence band densities of states of $\mathrm{CdIn}_{2} \mathrm{~S}_{4}$ and $\mathrm{In}_{2} \mathrm{~S}_{3}$ from X-ray photoelectron spectroscopy. Solid State Commun 1978; 28:563-5.

[18] Nomura R, Konishi K, Matsuda H. Single source organomettalic chemical vapour deposition process for sulfide thin films: Introduction of a new organometallic precursor $\mathrm{Bu}^{\mathrm{n}} \operatorname{In}\left(\mathrm{Spr}^{\mathrm{i}}\right)_{2}$. Thin Solid Films 1991; 198: 339-45.

[19] Mane RS, Lokhande CD. Studies on structural, optical and electrical properties of indium sulfide thin films. Mater Chem Phys 2003; 78: $15-17$

[20] Renjith R, John TT, Sudha Kartha C, Vijayakumar KP, Abe T, Kashiwaba Y. Post deposition annealing effect on $\operatorname{In}_{2} \mathrm{~S}_{3}$ thin films deposited using SILAR technique. Mater Sci Semicond Process 2007; 10: 49-55

[21] Ristov M, Sinadinovski GJ, Grozdanov I. Chemical deposition of $\mathrm{Cu}_{2} \mathrm{O}$ thin films. Thin Solid Films 1985; 123: 63-7.
[22] Kundakci M, Ates A, Astam A, Yildrim M. Structural, optical and electrical properties of $\mathrm{CdS}, \mathrm{Cd}_{0.5} \mathrm{In}_{0.5} \mathrm{~S}$ and $\mathrm{In}_{2} \mathrm{~S}_{3}$ thin films grown by SILAR method. Physica E 2008; 40: 600-5

[23] Nicolau YF. Solution deposition of thin solid compound films by a successive ionic-layer adsorption and reaction process. Appl Surf Sci 1985; 22/23:1061.

[24] Nicolau YF. Process and apparatus for the deposition on a substrate of a thin film of a compound containing at least one cationic constituent and at least one anionic constituent, US Patents $4675207,1985$.

[25] Resch R, Friedbacher G, Grassrebauer M, et al. Lateral force microscopy and force modulation microscopy on SILAR-grown lead sulfide samples. Appl Surf Sci 1997; 120: 51-7.

[26] Sankapal BR, Mane RS, Lokhande CD. Preparation and characterization of $\mathrm{Sb}_{2} \mathrm{~S}_{3}$ thin films using a successive ionic layer adsorption and reaction (SILAR) method. J Mater Sci Lett 1999; 18: 1453-5.

[27] Valkonen MP, Lindroos S, Rerch R, Leskela M, Friedbacher G, Grasserbauer M. Growth of Zinc sulphide thin films on(100) Si with the successive ionic layer adsorption and reaction method studied by atomic force microscopy. Appl Surf Sci 1998; 136: 1316.

[28] Ghosh B, Das M, Banerjee P, Das S. Fabrication of SnS thin films by the successive ionic layer adsorption and reaction (SILAR) method. Semicond Sci Technol 2008; 23: 125013.

[29] Yahmadi, Kamoun N, Bennaceur R, Manari M, Dachraoui M, Abdelkrim K. Structural analysis of indium sulphide thin films elaborated by chemical bath deposition. Thin Solid Films 2005; 473: 201-7.

(C) Warrier et al.; Licensee Bentham Open.

This is an open access article licensed under the terms of the Creative Commons Attribution Non-Commercial License (http://creativecommons.org/licenses/by$\mathrm{nc} / 3.0 /$ ) which permits unrestricted, non-commercial use, distribution and reproduction in any medium, provided the work is properly cited. 